to act altruistically," says Gilman. At present, Gilman plans to keep alliance laboratories based in North America, and plans regular teleconferencing using the broad-band Internet 2 to link people and computers at the various centres. Collaborators cannot be spread across too many time zones, he says, and Internet 2 does not yet exist outside the United States.

But he hopes that the international community can become involved in the second part of AFCS's work, the creation of 'molecule pages' describing detailed properties of proteins involved in the signalling pathways.

These pages, which will be peer reviewed by an editorial board and regularly updated, will be created as a web database - or what Gilman calls a "virtual journal" - by 'alliance members'. These are currently being sought. AFCS's steering group sent out letters to the research community last month, and has so far received 110 replies, 10 per cent from non-US scientists.

AFCS plans to develop tools for data management and analysis that must also be flexible enough to accommodate a variety of systems-modelling techniques.

Gilman hopes to raise half the running

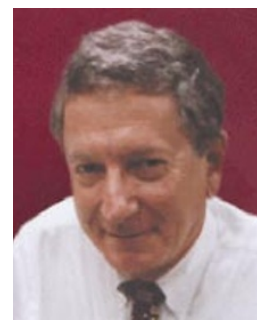

Gilman: creating a 'virtual journal'. costs from a new grant programme of the National Institutes of Health's National Institute for General Medical Sciences, which is designed for large-scale interdisciplinary approaches to problems in biology. The grant proposal has reached the second round of assessment, and a decision is expected in spring.

Using a model similar to that of the SNP consortium (see Nature 398, 545; 1998), Gilman wants to raise the other half of the money from a consortium of pharmaceutical companies. He says these "will in any case benefit from the information about signalling systems, which are important drug targets". He is asking for an annual contribution of $\$ 500,000$ from each commercial participant.

Tony Pawson, a researcher at the Samuel Lunenfeld Research Institute at the Mount Sinai Hospital in Toronto, says the AFCS concept is timely because scientists are starting to create their own databases of the interactions between cell-signalling molecules. But there is little coordination between them.

Pawson recently helped to launch a series of workshops under the auspices of the National Institutes of Health, the first of which was held in Washington last week. The aim is to help scientists talk to each other about where they can cooperate or merge their activities. He is talking to Gilman about how his own group's database, BIND (Biomolecular Interaction Network Database; http://bioinfo.mshri.on.ca) could cooperate, or even merge, with the AFCS databases.

Peter Seeburg, a director of the Max Planck Institute for Medical Research in Heidelberg, who studies mechanisms of action of membrane receptors, says that the initiative is "to be applauded". But because it is limited to two models, there is plenty of room for similar initiatives to be launched outside the project.

Axel Ullrich, director of the department for molecular biology at the Max Planck Institute for Biochemistry in Munich, says that the AFCS is "fantastic".

Full details of the new initiative can be found on http://afcs.swmed.edu Alison Abbott

\title{
Japan calls for partnership to develop semiconductors
}

Tokyo

A group of leading Japanese electronics companies has proposed a joint industry-government programme to develop next-generation semiconductor technology for the emerging system-on-achip (SoC) industry.

The proposal includes a plan to establish technical standards to enable intellectualproperty components from different sources to be mixed and matched, which is necessary for the building of custom SoCs embedded within complex systems.

The move reflects a feeling within Japan's semiconductor industry - which once dominated more than half the world market - that the recent technological and industrial shift towards logic-based products may lead to a further decline in its world share, which has dropped to 25 per cent.

The proposal was made by Semiconductor Industry Research Institute Japan (SIRIJ), an organization funded by leading Japanese semiconductor manufacturers, including Fujitsu, Hitachi, Matsushita, Mitsubishi Electric, NEC, Oki Electric Industry, Rohm, Sanyo, Sharp, Sony and Toshiba, to promote industrial research into silicon semiconductor technology.

The programme would involve all the companies involved in SIRIJ, and is expected to obtain support from the Ministry of

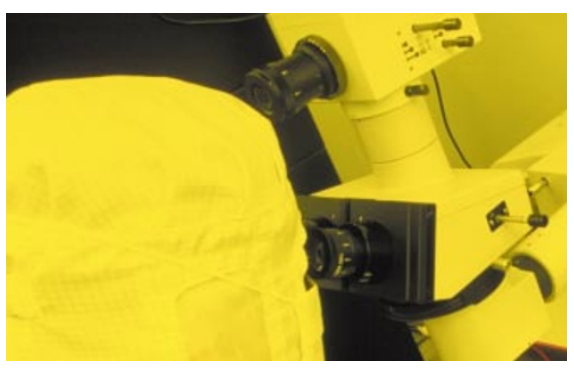

Looking for integration: Japanese companies want to work with government to develop chips.

International Trade and Industry (MITI) to set up a core research centre in 2001.

The programme would be modelled on Project Alba in Scotland, which brought together Scottish Enterprise - a government economic development body — and universities and industry from both within and outside Scotland to promote the research and development (R\&D) of SoC technology.

Although MITI says that the proposal is "not yet on the official agenda", industry sources say the plan is expected to be finalized by the end of this year and to be announced officially next spring.

"The Japanese semiconductor industry was slow to respond to paradigm changes in both technology and the market, as well as intensifying competition from Asian and US companies," says Tsuguo Makimoto, former director of Hitachi, who was instrumental in drawing up the proposal. Makimoto points out that Japan became too complacent about its dominance in memory-based technology, such as DRAM chips, in the 1980s. As a result, it "made very little effort in R\&D for semiconductor technology for nearly a decade, while the rest of the world moved on".

As the global semiconductor industry makes a shift towards highly integrated devices for digital information products, the development of SoC technology, which enables complex systems to be put onto a single piece of silicon, is seen as crucial.

Over the next five years, advances in technology may allow up to 200 million transistors to be placed on a single chip, yet few companies have the intellectual property or technology to use this capacity.

"In addition to legal and technological challenges, the lack of adequate human resources is a serious problem for the Japanese semiconductor industry," says Makimoto.

He says that Japan needs an organization similar to the US Semiconductor Technology Council to oversee policies in semiconductor research, as well as a central institution to promote joint industry-university research and to design new curricula at universities. "In short, we have to forget our past glories and start everything from scratch," says Makimoto.

Asako Saegusa 